\section{Learning to escape cues paired with reward reductions following single- or} multiple-pellet rewards

\author{
HELEN BOHMER DALY* \\ State University of New York, College at Oswego, Oswego, N.Y. 13126
}

In Experiment 1, three groups of rats were given 60 runway acquisition trials (6/day) to either one 500-mg pellet (Group 1L), 25 20-mg pellets (Group 25S), or one $20-\mathrm{mg}$ pellet (Group 1S). Rate of approach to asymptote was faster for Group 25S than for Group 1L, and at asymptote, they ran faster than Group 1S. All groups then received one 20-mg pellet for 30 trials. Group 25S showed a greater depression effect than did Group 1L. The acquisition results were replicated in Experiment 2, and, during a third phase in which Ss were given hurdle-jump training, both shifted groups jumped faster than Group 1S, but Group 25S jumped the fastest. It was concluded that greater amounts of frustration are elicited when both reward magnitude and number of pellets are reduced than when only reward magnitude is reduced.

Many studies have demonstrated that the strength of a simple instrumental response at asymptote is directly related to the magnitude of the reward received (cf. Bitterman \& Schoel, 1970). McCain (1969) has pointed out, though, that many of them have confounded reward magnitude with number of pellets. Recent studies which have equated groups for number of pellets by using one large and one small pellet have not obtained differences at asymptote between groups receiving different reward magnitudes (e.g., Black, 1969; McCain, Dyleski, \& McElvain, 1971). When reward magnitude has been equated but number of pellets has varied, the group receiving many small pellets has performed more rapidly than the group receiving one large pellet (McCain, 1969). Although McCain (1969) found these differences to be significant at asymptote, Amsel, Surridge, \& Hug (1969) and Traupmann (1971) found that differences did not appear, or disappeared, with more extended training. Many incentive-shift experiments (cf. Crespi, 1942) have confounded reductions in magnitude of reward with reductions in number of pellets, although the depression effect has been obtained when reward magnitude was reduced from one large pellet to one small pellet (e.g., Spence, 1956).

The purposes of the present experiments were: (1) to provide additional data on the effects of reward magnitude with number of pellets equated and on the effects of multiple- vs single-pellet rewards with

*This research was supported by NIMH Grant 17398. The author wishes to thank Lynn Tondat for assistance in the conduct of the experiment and the statistical analyses. reward magnitude equated, (2) to determine if the magnitude of the depression effect is influenced by multiple- vs single-pellet rewards in acquisition, and, if so, (3) to measure whether or not the difference in the magnitude of the depression effect is due to amount of frustration elicited during the incentive-shift phase. This was done by measuring the rate of learning of a new response (hurdle-jump response) to escape the cues paired with the reduced reward. SUBJECTS

In Experiment 1, male Holtzman rats $(N=45, n=15)$ obtained from Holtzman Co., Madison, Wisconsin, 85-99 days old, weighing 340-398 g prior to deprivation, were fed Big Red laboratory rat chow for $1 \mathrm{~h} /$ day, which reduced Ss to $86 \%$ of their original body weights. In Experiment 2, male Holtzman rats $(\mathrm{N}=42, \mathrm{n}=14)$ approximately 95 days old, weighing $315-379 \mathrm{~g}$ prior to deprivation, were fed Big Red laboratory chow for $50 \mathrm{~min} / \mathrm{day}$, which reduced Ss to $84 \%$ of their original body weights. The mean weights of the various groups did not differ from each other during the course of the experiments, Fs $<1$.

$$
\text { APPARATUS }
$$

The white alley consisted of a $30.5-\mathrm{cm}$ startbox, $139.7 \cdot \mathrm{cm}$ runway, and $27.9-\mathrm{cm}$ goalbox, $14.0 \mathrm{~cm}$ high and $11.4 \mathrm{~cm}$ wide. A startbox door which opened sideways controlled the start of each trial and activated a silent switch connected to a Hunter Klockounter. Interruption of photobeams, $15.2 \mathrm{~cm}, 137.2 \mathrm{~cm}$, and $157.5 \mathrm{~cm}$ from the door and connected to Hunter photorelays and Klockounters, measured start, runway, and goal times, respectively. Interruption of the last photobeam controlled the onset of a light in the goalbox during the appropriate phases of Experiment 2. A goalbox door prevented retracing. The $\mathrm{Ss}$ received the designated number of pellets (P. J. Noyes Co., Formula A) in a white measuring spoon hanging from the wall at the end of the alley on the left side, $8.26 \mathrm{~cm}$ from the floor. The spoon was bent up so that it was impossible for Ss to see the pellets before they broke the last photobeam. Sanded Plexiglas covered the alley.

In Experiment 2, the hurdle-jump section was also used. This section consisted of a startbox (which was the goalbox of the alley) and a goalbox which was attached to the end of the startbox. The start- and goalboxes were separated by a door $(10.2 \times 6.4 \mathrm{~cm})$ which rested on a hurdle, $5.1 \mathrm{~cm}$ high, and opened in an upward direction. The goalbox of the h u rd le - j u m p a p a r a t u s $(11.4 \times 27.9 \times 14.0 \mathrm{~cm})$ was painted medium gray and had a wire mesh top with sanded Plexiglas above it. The time from raising the door to the breaking of a photobeam $10.2 \mathrm{~cm}$ from the hurdle was measured by a Hunter Klockounter.

\section{PROCEDURE}

Eight days following the beginning of the deprivation schedule in Experiment 1, Ss were taken to the experimental room and placed in an un painted wooden box $(26.7 \times 11.4 \times 15.2 \mathrm{~cm})$ with a wire mesh top and solid bottom and received in an unpainted measuring spoon the number and size of pellets they would receive in the alley. On the next day, Phase 1 of the experiment began. All Ss received two trials in the alley on the first day, four trials the next day, and six trials per day thereafter. A trial began with $S$ being placed in the startbox. After $S$ had faced the startbox door for $3 \mathrm{sec}$, the door was opened and $\mathrm{S}$ was allowed to run down the alley. The goalbox door was closed when the last photobeam was broken. Group $1 \mathrm{~L}$ received one large (500-mg) pellet, Group 25S received 25 small (20-mg) pellets, and Group $1 \mathrm{~S}$ received one small $(20-\mathrm{mg})$ pellet on every trial. Groups $1 \mathrm{~L}$ and $25 \mathrm{~S}$ were removed from the goalbox when they finished eating, and Group 1S was left in the goalbox for approximately $10 \mathrm{sec}$ and then returned to retaining cages (water available). On the 5 days following the 60 th acquisition trial, all Ss were given six trials per day and received one small pellet (Phase 2). All Ss were removed from the goalbox after 10 sec.

The procedure used in Experiment 2 was identical to that of Experiment 1, except that (1) on the day before the beginning of Phase 1 , Ss were placed in the goalbox of the 

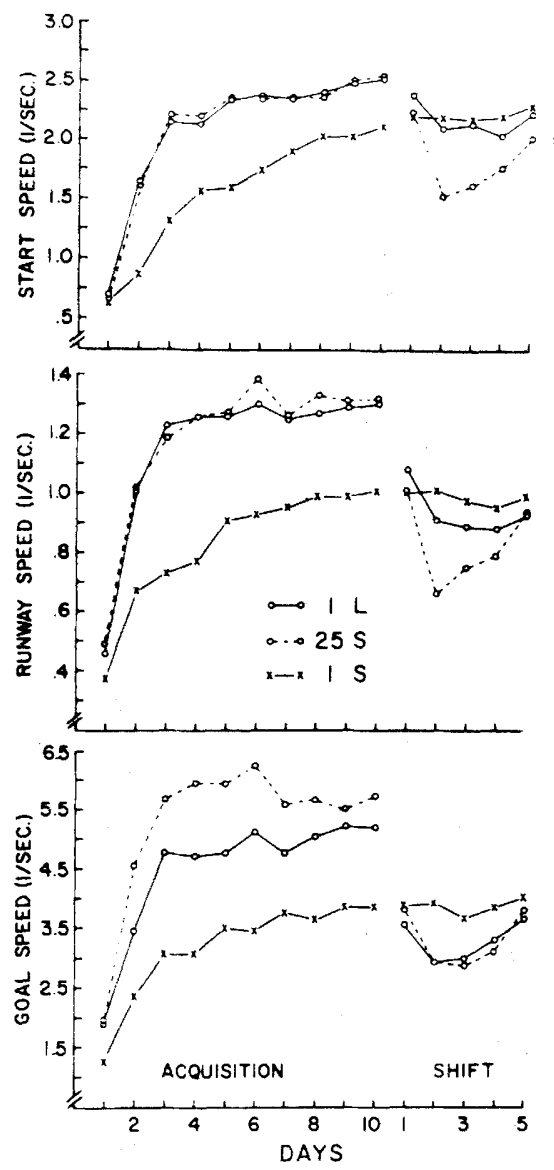

Fig. 1. Mean start, runway, and goal speeds ( $1 / \mathrm{sec}$ ) per day (six trials/day) for the acquisition and shift phases of Experiment 1.

hurdle-jump apparatus for $7 \mathrm{~min}$, (2) during Phase 2, Ss received only 1 day of training (six trials) and a light came on in the goalbox of the alley as $S$ broke the third photobeam, and (3) $\mathrm{Ss}$ were given 2 days of hurdle-jump training (15 and 12 trials/day, respectively) following Phase 2 (Phase 3). During Phase 3 , S was placed in the startbox of the hurdle-jump apparatus (the goalbox of the alley) and the light came on. Ten seconds later the door was raised. After jumping, $S$ remained in the goalbox of the hurdle-jump apparatus for $10 \mathrm{sec}$ and was then returned to the retaining cages. If $S$ did not jump within $60 \mathrm{sec}$, he was removed from the startbox and a latency of $60 \mathrm{sec}$ was recorded. All Ss received one small pellet in the startbox of the hurdle-jump apparatus during Phase 3.

The Ss were run in squads of nine, three Ss from each group, with an intertrial interval of 6-7 min during Phases 1 and 2 and 5-8 $\mathrm{min}$ during Phase 3. The order of Ss run within each squad was random but remained constant over days. Two Es ran all Ss. However, both Es handled Ss prior to the acquisition phase, and no $\mathrm{E}$ ran an $S$ for more than 2 days in a row. RESULTS

Mean speeds $(1 / \mathrm{sec})$ per day for the runway acquisition and the incentive shift phases are presented in Fig. 1 for Experiment 1 and in Fig. 2 for Experiment 2. Groups by Days (3 by 10) analyses of variance done on Phase 1 data indicated a significant groups effect, $F(2,42)=35.72,60.52$, and $42.77, \mathrm{p}<.001$, a significant days effect, $F(9,378)=200.42,162.89$, and $97.78, \quad \mathrm{p}<.001$, and a significant Groups by Days interaction, $\mathrm{F}(18,378)=4.06,4.32$, and 3.81 , $\mathrm{p}<.001$, for the start, runway, and goal measures, respectively, for Experiment 1, and a significant groups effect, $F(2,39)=61.10,28.56$, and $27.74, \quad \mathrm{p}<.001$, a significant days effect, $F(9,351)=126.65,225.29$, and $130.27, \mathrm{p}<.001$, and a significant Groups by Days interaction, $F(18,351)=2.53, \quad 5.86$, and 5.04, $\mathrm{p}<.001$, for the start, runway, and goal measures, respectively, for Experiment 2. To test for groups effects early, middle, and late in training, separate simple analyses of variance were done on the data for Days 1, 6, and 10. On Day 1 data, there were no groups effects, Fs $<1$, on the start and runway measures for Experiments 1 and 2, but on the goal measure, there was, $F(2,42)=7.17$, p $<.01$, for Experiment 1 and $F(2,39)=4.66, \quad p<.05$, for Experiment 2. Newman-Keuls tests $(p=.05)$ indicated that on the goal measure, Group 1S ran more slowly than the other two groups in Experiment 1 and Group $1 S$ ran more slowly than Group $25 \mathrm{~S}$ in Experiment 2. However, an analysis of Trial 1 data indicated no significant differences among the groups for Experiments 1 and 2, ps $>.05$. On Day 6 data, there were significant groups effects, $F(2,42)=16.97,18.33$, and $33.67, p<.001$, for the start, runway, and goal measures, respectively, for Experiment 1 and $F(2,39)=26.96,15.11$, and 50.55 , $\mathrm{p}<.001$, for the start, runway, and goal measures, respectively, for Experiment 2. Newman-Keuls tests $(p=.05)$ indicated that on the start and runway measures, Groups $1 \mathrm{~L}$ and $25 \mathrm{~S}$ ran faster than Group $1 \mathrm{~S}$ but did not differ from each other in both Experiments 1 and 2. On the goal measure, Group 25S ran faster than Groups $1 \mathrm{~L}$ and $1 \mathrm{~S}$ and Group $1 \mathrm{~L}$ ran faster than Group 1S in both experiments. On Day 10 data, there were significant groups effects, $F(2,42)=21.62,26.26$, and 19.96, $\mathrm{p}<.001$, for the start, runway, and goal measures, respectively, in Experiment 1 and $F(2,39)=13.71$, 17.28 , and $11.99, \mathrm{p}<.001$, for the
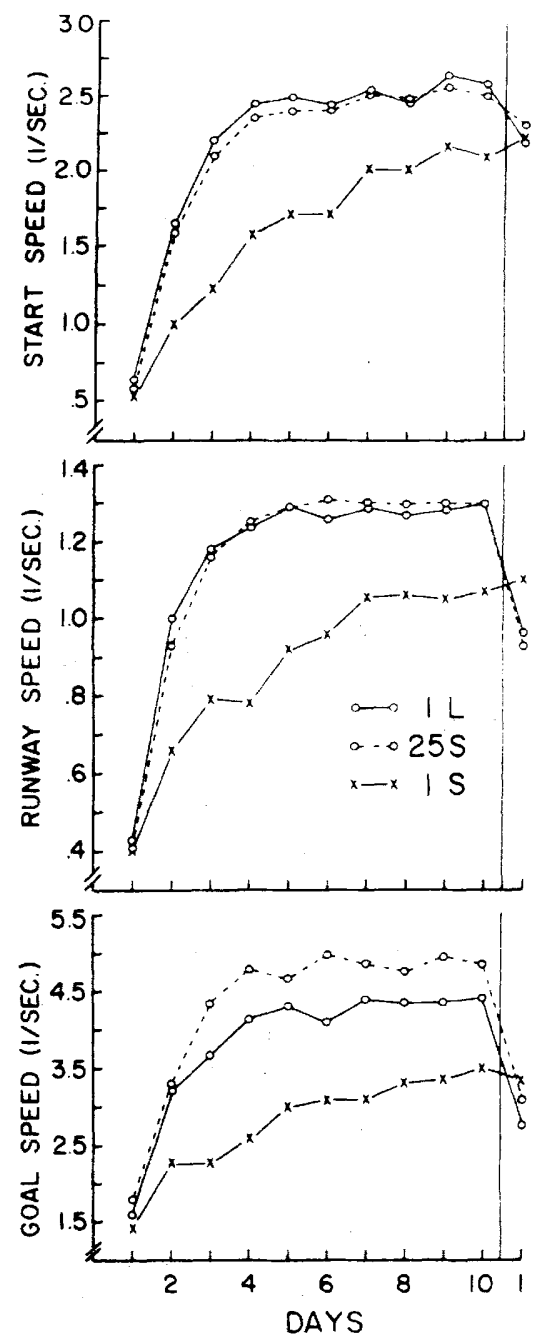

Fig. 2. Mean start, runway, and goal speeds (1/sec) per day (six trials/day) for the acquisition and shift phases of Experiment 2.

start, runway, and goal measures, respectively, for Experiment 2 . Newman-Keuls tests $(p=.05)$ indicated that Groups $1 \mathrm{~L}$ and $25 \mathrm{~S}$ ran faster than Group 1S but did not differ from each other on all response measures in both experiments.

Groups by Days ( 3 by 5 ) analyses of variance done on the Phase 2 data of Experiment 1 indicated a significant groups effect, $F(2,42)=4.38,17.48$, and $4.20, \mathrm{p}<.05$, and a significant days effect, $F(4,168)=13.19,12.28$, and $85.02, p<.001$, for the start, runway, and goal measures, respectively. The Groups by Days interaction was also significant on the start and runway measures, $F(8,168)=3.93$ and 6.87, $p<.001$, but not on the goal measure, $F(8,168)=1.52, \quad p>.05$. Separate simple analyses of variance on Day 3 data indicated significant groups effects, $\quad F(2,42)=6.41, \quad 7.35$, and 


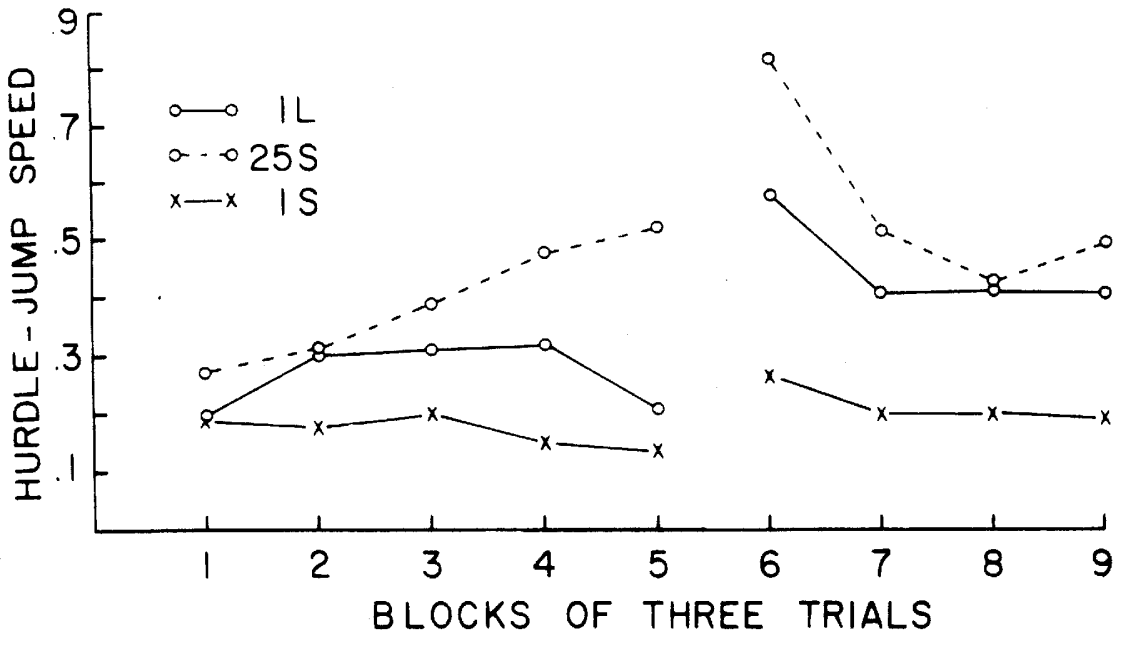

Fig. 3. Mean hurdle-jump speeds $(1 / \mathrm{sec})$ per three-trial blocks for the first and second day of hurdle jumping of Experiment 2.

$4.29, \mathrm{p}<.05$, for the start, runway, and goal measures, respectively. Newman-Keuls tests $(\mathrm{p}=.05)$ indicated that: (1) on the start measure, Group 25S ran more slowly than Groups $1 \mathrm{~L}$ and $1 \mathrm{~S},(2)$ on the runway measure, Group 25S ran more slowly than Group 1S, and (3) on the goal measure, Groups 25S and $1 \mathrm{~L}$ both ran more slowly than Group 1S. Analyses of variance on Day 5 data indicated that there were no group differences on any measure, $F s<1$.

Mean speeds ( $1 / \mathrm{sec})$ of hurdle jumping for Experiment 2 per three-trial blocks are presented in Fig. 3. A Groups by Trial Blocks analysis of variance ( 3 by 9 ) indicated a significant groups effect, $F(2,39)=17.67, \quad p<.001$, a significant trial blocks effect, $\mathrm{F}(8,312)=8.51, \quad \mathrm{p}<.001$, and $\mathrm{a}$ significant Groups by Trial Blocks interaction, $\mathrm{F}(16,312)=2.02, \mathrm{p}<.05$. Because of the significant interaction effect, separate analyses of variance were done on each trial block. There were no groups effects on Trial Blocks 1,8 , or $9, \mathbf{F}(2,39)=1.13,2.86$, and $2.95, \mathrm{p}>.05$, respectively. However, there were significant groups effects on Trial Blocks 2, 3, 4, 5, 6, and 7, $\mathrm{F}(2,39)=4.91, \quad 4.79, \quad 6.00, \quad 10.51$, 16.08 , and 7.21, p<.05-.001, respectively. Newman-Keuls tests $(p=.05)$ indicated: (1) Groups 25S and $1 \mathrm{~L}$ jumped faster than Group $1 \mathrm{~S}$ on Trial Block 2, (2) Group 25S jumped faster than Group 1S on Trial Blocks 3 and 4, (3) Group $25 \mathrm{~S}$ jumped faster than Groups $1 \mathrm{~S}$ and $1 \mathrm{~L}$ on Trial Block 5, (4) Group 25S jumped faster than Groups $1 \mathrm{~L}$ and $1 \mathrm{~S}$ and Group 1L jumped faster than Group $1 \mathrm{~S}$ on Trial Block 6 , and (5) Groups $25 \mathrm{~S}$ and $1 \mathrm{~L}$ jumped faster than Group 1S on Trial Block 7.

\section{DISCUSSION}

The present data support the position that asymptotic performance of an instrumental response is a function of reward magnitude and that number of pellets only influences rate of approach to asymptote. Following 60 acquisition trials (a sufficient number to reach asymptote according to McCain et al, 1971), Groups 25S and $1 \mathrm{~L}$ did not differ from each other, although Group 25S ran faster than Group $1 \mathrm{~L}$ on the goal measure halfway through training. Groups $25 \mathrm{~S}$ and $1 \mathrm{~L}$ ran faster than Group is on all three measures throughout acquisition. The lack of difference between Groups 1L and $25 \mathrm{~S}$ at the end of acquisition on the goal measure must be accepted with caution, however, since the graph does indicate a small difference. However, these data agree with those of Amsel et al (1969) and Traupmann (1971) and not with those of McCain et al (1971). Additional research will have to be done to determine what procedural variations are causing the differences among the results of the studies. Possible differences include time in the goalbox (e.g., Cilluffo \& Black, 1970), number of acquisition trials, time vs speed scores (Traupmann \& Wong, 1971), type of deprivation schedule, and exploration of the unbaited runway prior to acquisition.

According to frustration theory (Amsel, 1958; Daly, 1969), the depression effect is due to the elicitation of the aversive motivational response, frustration, when a small reward is experienced in the presence of cues conditioned to elicit an expectancy of a large reward during acquisition. The frustration response becomes conditioned to the cues of the goalbox and through stimulus generalization is elicited earlier in the alley. The competing responses associated with frustration disrupt approach behavior. This disruption is measured by comparing the speeds of the shifted group with those of a control group that is conditioned throughout training to expect the small reward. The results of Experiment 1 indicated that when number of pellets was held constant, reductions in reward magnitude resulted in frustration, since Group $1 \mathrm{~L}$ ran more slowly than Group $1 \mathrm{~S}$ in the shift phase. However, Group 25S showed a greater depression effect on the start and runway measures than did Group $1 \mathrm{~L}$, indicating that a shift in number of pellets in addition to a reduction in reward magnitude aroused a greater amount of frustration than when only the reward magnitude was reduced.

Speed of hurdle jumping is presumed to reflect the amount of frustration aroused by the small reward and has been shown to be a good measure of frustration aroused in other change-in-reward studies (e.g., Daly, 1969). During the hurdle-jump phase of Experiment 2, Groups 1L and $25 \mathrm{~S}$ jumped the hurdle faster than Group 1S, but Group 25S jumped faster than Group 1L. These data provide additional evidence for the conclusion that greater amounts of frustration are elicited when both reward magnitude and number of pellets are reduced than when only reward magnitude is reduced.

\section{REFERENCES}

AMSEL, A. The role of frustrative nonreward in noncontinuous reward situations. Psychological Bulletin, 1958 , 55, 102-119.

AMSEL, A., SURRIDGE, C. T., \& HUG, J. J. Number of food pellets and the partial reinforcement extinction effect after extended acquisition. Journal of Experimental Psychology, 1969, 82, 578-580.

BITTERMAN, M. E., \& SCHOEL, W. M Instrumental learning in animals: Parameters of reinforcement. In Annual Review of Psychology. Vol. 21. Palo Alto, Calif: Annual Reviews, 1970. Pp. 367-436.

BLACK. R. W. Incentive motivation and the parameters of reward in instrumental conditioning. In $\mathrm{W}, \mathrm{J}$. Arnold and $\mathrm{D}$ Levine (Eds.), Nebraska symposium on motivation. Lincoln: University of Nebraska Press, 1969.

CILLUFFO, A., \& BLACK, R. W. Runway performance maintained by multiple rewards per trials. Psychonomic Science, $1970,19,19-21$.

CRESPI, L. P. Quantitative variation in incentive and performance in the white rat. American Journal of Psychology, $1942,55,467-517$.

DALY, H. B. Learning of a hurdle-jump response to escape cues paired with reduced reward or frustrative nonreward. Journal of Experimental Psychology, $1969,79,146-157$.

McCAIN, G. Different levels of performance with equivalent weights of reward. 
Psychonomic Science, 1969, 14, 2-3. McCAIN, G., DYLESKI, K., \& McELVAIN, G. Reward magnitude and instrumental responses: Consistent reward. Psychonomic Monograph Supplements, $1971,3(16$, Whole No. 48$)$.
SPENCE, K. W. Behavior theory and conditioning. New Haven: Yale University Press, 1956.

TRAUPMANN, K. L. Acquisition and extinction of an instrumental running response with single- or multiple-pellet reward. Psychonomic Science, 1971,22, 61-63.

TRAUPMANN, K. L., \& WONG, P. T. P. Reward magnitude and instrumental responses: A comment. Psychonomic Science, 1971, 23, 13-14.

\section{Preferences}

ALLISON, J. Microbehavioral features of nutritive and nonnutritive drinking in rats. Journal of Comparative \& Physiological Psychology, 1971, 76, 408-417.

BAUER, F. S. Glucose preference in the guinea pig. Physiology \& Behavior, 1971, 6, 75-76.

CAREY, R. J. Quinine and saccharin preference-aversion threshold determinations in rats with septal ablations. Journal of Comparative \& Physiological Psychology, 1971, 76, 316-326.

FLAHERTY, C. F., \& HAMILTON, L. W. Responsivity to decreasing sucrose concentrations following septal lesions in the rat. Physiology \& Behavior, 1971, 6, 431-437.

McCUTCHEON, N. B. Sensory adaptation and incentive contrast as factors affecting $\mathrm{NaCl}$ preference. Physiology \& Behavior, 1971, 6, 675-680.

MILLER, C. R., ELKINS, R. L., \& PEACOCK, L. J. Disruption of a radiation-induced preference shift by hippocampal lesions. Physiology \& Behavior, 1971, 6, 283-285.

NACHMAN, M., LARUE, C., \& Le MAGNEN, J. The role of olfactory and orosensory factors in the alcohol preference of inbred strains of mice. Physiology \& Behavior, 1971, 6, 53-95.

REVUSKY, S. H., SMITH, M. H., JR., \& CHALMERS, D. V. Flavor preference: Effects of ingestion-contingent intravenous saline or glucose. Physiology \& Behavior, 1971, 6, 341-343.

STROUTHES, A. Thirst and saccharin preference in rats. Physiology \& Behavior, 1971, 6, 287-292.

WAGNER, M. W. Comparative rodent preferences for artificial sweeteners. Journal of Comparative \& Physiological Psychology, 1971, 75, 483-490.

\section{Appetites and Self-Selection}

CHIAR A VIGLIO, E. Amygdaloid modulation of sodium chloride and water intake in the rat. Journal of Comparative \& Physiological Psychology, 1971, 76, 401-407.

HARRIMAN, A. E. Inadequate intakes of $\mathrm{NaCl}$ by adrenalectomized rats given a $20 \%$ dextri-maltose solution opposite a $1.5 \% \mathrm{NaCl}$ solution. Journal of General Psychology, $1971,85,115-121$.

HUGHES, B. O., \& WOOD-GUSH, D. G. M. Investigations into specific appetites for sodium and thiamine in domestic fowls. Physiology \& Behavior, 1971, 6, 331-339.

LESHNER, A. I., COLLIER, G. H., \& $S Q U I B B, \quad R$. L. Dietary self-selection at cold temperatures. Physiology \& Behavior, 1971, 6, 1-3.

WOLF, G. Neural mechanisms for sodium appetite: Hypothalamus positive-hy pothalamofugal pathways negative. Physiology \& Behavior, 1971, 6, 381-389.

\section{Drug Effects}

BAUER, E. R. Schedule and quinine induced deprivation in feeding and refeeding. Physiology \& Behavior, 1971, 6, 87-90.

DISSINGER, M. L., \& CARR, W. J. Effects of tertiary vs quaternary scopolamine on water and air drinking in rats. Psychonomic Science, 1971, 25, 17-18.

HOLLOWAY, F. A., \& VARDIMAN, D. R. Dose-response effects of ethanol on appetitive behaviors. Psychonomic Science, 1971, 24, 218-220.

JACOBS, B. L., \& FAREL, P. B. Motivated behaviors produced by increased arousal in the presence of goal objects. Physiology \& Behavior, $1971,6,473-476$.

LOVETT, D., \& SINGER, G. Ventricular modification of drinking and eating behavior. Physiology \& Behavior, 1971, 6, 23-26.

NEILL, D. B., \& GROSSMAN, S. P. Interaction of the effects of reserpine and amphetamine on food and water intake. Journal of Comparative \& Physiological Psychology, 1971, 76, 327-336.

SCHROT, J. F., HAWKINS, T. D., \& GITHENS, $S$. $H$. The effects of alcohol concentration on schedule-induced alcohol drinking. Psychonomic Science, 1971, 24, 201-202.

SELIGMAN, M. E. P., MINEKA, S., \& FILLIT, $H$. Conditioned drinking produced by procaine, $\mathrm{NaCl}$, and angiotensin. Journal of Comparative \& Physiological Psychology, 1971, $77,110-121$.

Sexual and Maternal Behavior

ALLEN, J. A., \& BOICE, R. Effects of rearing on homosexual behavior in the male laboratory rat. Psychonomic Science, 1971, 23, 321-322.

BOLAND, B. D., \& DEWSBURY, D. A. Characteristics of sleep following sexual activity and wheel running in male rats. Physiology \& Behavior, 1971, 6, 145-149.

BRANCHEY, M., BRANCHEY, L., \& NADLER, R. D. Effects of estrogen and progesterone on sleep patterns of female rats. Physiology \& Behavior, 1971, 6, 743-746.

DIAKOW, C. Effects of genital desensitization on mating behavior and ovulation in the female cat. Physiology \& Behavior, 1971, 7, 47-54.

EDWARDS, D. A. Neonatal administration of androstenedione, testosterone or testosterone propionate: Effects on ovulation, sexual receptivity and aggressive behavior in female mice. Physiology \& Behavior, 1971, 6, 223-228.

GOODMAN, E. D., JANSEN, P. E., \& DEWSBURY, D. A. Midbrain reticular formation lesions: Habituation to stimulation and copulatory behavior in male rats. Physiology \& Behavior, 1971, 6, 151-156.

LARSSON, K., \& SWEDIN, G. The sexual behavior of male rats afterbilateral section of the hypogastric nerve and removal of the accessory genital glands. Physiology \& Behavior, 1971, 6, 251-253.

MOLTZ, H., LEON, M., NUMAN, M., \& LUBIN, $M$. Replacement of progesterone with a phenothiazine in the induction of maternal behavior in the ovariectomized nulliparous rat. Physiology \& Behavior, 1971, 6, 735-737.

VAN DIS, H., \& LARSSON, K. Induction of sexual arousal in the castrated male rat by intracranial stimulation. Physiology \& Behavior, $1971,6,85-86$. 


\section{Fear}

BADIA, P., CULBERTSON, S., DEFRAN, R. H., \& LEWI'S, P. Attenuation of rat vocalizations to shock by a stimulus: Sensory interaction effects? Journal of Comparative \& Physiological Psychology, 1971, 76, 131-136.

BROWN, G. E., \& REMLEY, N. R. The effects of septal and olfactory bulb lesions on stimulus reactivity. Physiology \& Behavior, 1971, 6, 497-501.

CAPALDI, E. J., BERG, R. F., \& SPARLING, D. L. Trial spacing and emotionality in the rat. Journal of Comparative \& Physiological Psychology, 1971, 76, 290-299.

HORVATH, T., KIRBY, H. W., \& SMITH, A. A. Rats' heart rate and grooming activity in the open field. Journal of Comparative \& Physiological Psychology, 1971, 76, 449-453.

I R W I N, S., KINOHI, R., VAN SLOTEN, M., \& WORKMAN, M. P. Drug effects on distress-evoked behavior in mice: Methodology and drug class comparisons. Psychopharmacologia (Berlin), 1971, 20, 172-185.

PAPPAS, B. A., \& GRAY, P. Cue value of dexamethasone for fear-motivated behavior. Physiology \& Behavior, 1971, 6, 127-130.

STRENG, J. Open-field behavior in four inbred mouse strains. Canadian Journal of Psychology, 1971, 25, 62-68.

THORNE, B. M.; \& LINDER, L. H. No change in emotionality of rats following bulbectomy. Psychonomic Science, 1971, 24, 207-208.

ULM, R. R., \& CICALA, G. A. Reliable immobility and activity enhancement are produced by a fear CS. Psychonomic Science, 1971, 24, 143-144.

VALLE, F. P. Rats' performance on repeated tests in the open field as a function of age. Psychonomic Science, 1971, 23, 333-335.

WIMER, C. C., WIMER, R. E., \& RODERICK, T. H. Some behavioral differences associated with relative size of hippocampus in the mouse. Journal of Comparative \& Physiological Psychology, 1971, 76, 57-65.

\section{Sleep and Immobility}

FISHBEIN, W. Disruptive effects of rapid eye movement sleep deprivation on long-term memory. Physiology \& Behavior, 1971, 6, 279-282.

GALLUP, G. G., JR., NASH, R. F., \& WAGNER, A. M. The tonic immobility reaction in chickens: Response characteristics and methodology. Behavior Research Methods \& Instrumentation, 1971, 3, 237-239.
IRMIS, F., LAT, J., \& RADIL-WEISS, $T$. Individual differences in hippocampal EEG during rhombencephalic sleep and arousal. Physiology \& Behavior, 1971, 7, 117-119.

JOHNSON, D. N., FUNDERBURK, • W. H., \& WARD, J. W. Effects of fenfluramine on sleep-wakefulness in cats. Psychopharmacologia (Berlin), 1971, 20, 1-9.

MILLER, L., DREW, W. G., \& SCHWARTZ, I. Effect of REM sleep deprivation on retention of a one-trial passive avoidance response. Perceptual \& Motor Skills, 1971, 33, 118.

MORALES, F. R., ROIG, J. A., MONTI, J. M., MACADAR, O., \& BUDELLI, R. Septal unit activity and hippocampal EEG during the sleep-wakefulness cycle of the rat. Physiology \& Behavior, 1971, 6, 563-567.

SATINOFF, E., DRUCKER-COLÍN, R. R., \& HERNÁNDEZ-PEÓN, R. Paleocortical excitability and sensory filtering during REM sleep deprivation. Physiology \& Behavior, 1971, 7, 103-106.

TESSIER, J., \& JASPER, H. H. Acetylcholine liberation from cerebral cortex during paradoxical (REM) sleep. Science, 1971, 172, 601-602.

WEBB, W. B., \& FRIEDMAN, J. Attempts to modify the sleep patterns of the rat. Physiology \& Behavior, 1971, 6, 459-460.

\section{SOCIAL AND}

ABNORMAL BEHAVIOR

BOICE, $R$. Laboratorizing the wild rat (Rattus norvegicus). Behavior $\mathrm{R}$ esearch Methods \& Instrumentation, $1971,3,177-182$.

FISCHER, G. J. Developmental changes in chick approach preference for social and food stimuli. Developmental Psychology, $1971,4,155-157$

FLORY, R. K., \& FRENCH, K. Social disruption of discriminated avoidance behavior. Psychonomic Science, 1971, 24, 39-40.

GALEF, B. G., JR. Social effects in the weaning of domestic rat pups. Journal of Comparative \& Physiological Psychology, 1971, 75, 358-362.

GALEF, B. G., JR., \& CLARK, M. M. Social factors in the poison avoidance and feeding behavior of wild and domesticated rat pups. Journal of Comparative \& Physiological Psychology, 1971, 75, 341-357.

GARDNER, E. L., \& ENGEL, D. R. Imitational and social facilitatory aspects of observational learning in the laboratory rat. Psychonomic Science, $1971,25,5-6$.

HARPER, L. V. The young as a source of stimuli controlling caretaker beh avior. Developmental Psychology, 1971, 4, 73-88.

JAMES, W. T. A methodological study of conditioning and extinction of an avoidance response via social facilitation in dogs. Journal of General Psychology, 1971, 84, 275-279.

LATANÉ, B., \& WERNER, C. Social and nonsocial sources of attraction in rats. Psychonomic Science, 1971, 24, 147-148.

NEWELL, T. G. Social encounters in two prosimian species: Galago crassicaudatus and Nycticebus coucang. Psychonomic Science, 1971, 24, 128-130.

ROSENBAUM, M. E., \& EPLEY, S. W. Cooperation in rats without prior individual training. Psychonomic Science, 1971, 24, 34-36.

TAYLOR, C. J., \& ERSPAMER, R. A method for the measurement of cooperative behavior in albino rats. Psychological Record, 1971, 21, 121-124.

\section{Aggression}

BRAIN, P. F., NOWELL, N. W., \& WOUTERS, A. Some relationships between adrenal function and the effectiveness of a period of isolation in inducing intermale aggression in albino mice. Physiology \& Behavior, 1971, 6, 27-29.

CHEREK, D. R., \& HEISTAD, G. T. Fixed-interval-induced aggression. Psychonomic Science, 1971, 25, 7-8.

CREER, T. L., \& POWELL, D. A. Effect of repeated shock presentations and different stimulus intensities on shock-induced aggression. Psychonomic Science, $1971,24,133-134$.

DAVIS, W. M., \& KHALSA, J. H. Some determinants of aggressive behavior induced by morphine withdrawal. Psychonomic Science, $1971,24,13-15$.

E DWAR DS, D. A. Neonatal administration of androstenedione, testosterone or testosterone propionate: Effects on ovulation, sexual receptivity and aggressive behavior in female mice. Physiology \& Behavior, 1971, 6, 223-228.

FLANDERA, V., \& NOVÁKOVÁ, V. The development of interspecies aggression of rats towards mice during lactation. Physiology \& Behavior, 1971, 6, 161-164.

FLYNN, J. P., \& CHI, C. C. Neural pathways associated with hypothalamically elicited attack behavior in cats. Science, 1971, 171, 703-705.

LEE, C. T., \& BRAKE, S. C. Reactions of male fighters to male and female mice, untreated or deodorized. Psychonomic Science, 1971, 24, 209-211. 
MUGFORD, R. A., \& NOWELL, N. W. The preputial glands as a source of aggression-promoting odors in mice. Physiology \& Behavior, 1971, 6, 247-249.

PANKSEPP, J. Aggression elicited by electrical stimulation of the hypothalamus in albino rats. Physiology \& Behavior, 1971, 6, 321-329.

PANKSEPP, J. Drugs and stimulus-bound attack. Physiology \& Behavior, 1971, 6, 317-320.

PANKSEPP, J. Effects of hypothalamic lesions on mouse-killing and shock-induced fighting in rats. Physiology \& Behavior, 1971, 6, 311-316.

PAUL, L., MILEY, W. M., \& BAENNINGER, R. Mouse killing by rats: Roles of hunger and thirst in $i$ its initiation and maintenance. Journal of Comparative \& Physiological Psychology, 1971, 76, 242-249.

PAYNE, A. P., \& SWANSON, H. H. Hormonal control of aggressive dominance in the female hamster. Physiology \& Behavior, 1971, 6, 355-357.

RIEDER, C. A., \& REYNIERSE, J. H. Effects of maintenance condition on aggression and marking behavior of the Mongolian gerbil (Meriones unguiculatus). Journal of Comparative \& Physiological Psychology, 1971, 75, 471-475.

SCHROLD, J., \& SQUIRES, R. F. Behavioural effects of d-amphetamine in young chicks treated with p-Cl-phenylalanine. Psychopharmacologia (Berlin), 1971, 20, 85-90.

SCOTT, J. P., LEE, C.-T., \& HO, J. E. Effects of fighting, genotype, and amphetamine sulfate on body temperature of mice. Journal of Comparative \& Physiological Psychology, 1971, 76, 349-352.

SHAPIRO, S., \& SCHUCKMAN, H. Habituation and covariation of the components of the threat display in Betta splendens. Psychological Reports, 1971, 28, 827-837.

THOR, D. H. Amphetamine induced fighting during morphine withdrawal. Journal of General Psychology, 1971, 84, 245-250.

WOLFE, M., ULRICH, R., \& DULANEY, S. Fighting and escape reaction in paired rats. Psychological Record, 1971, 21, 59-68.

WOODWORTH, C. H. Attack elicited in rats by electrical stimulation of the lateral hypothalamus. Physiology \& Behavior, 1971, 6, 345-353.

Territoriality

RALLS, K. Mammalian scent marking. Science, 1971, 171, 443-449.
RIEDER, C. A., \& REYNIERSE, J. H. Effects of maintenance condition on aggression and marking behavior of the Mongolian gerbil (Meriones unguiculatus). Journal of Comparative \& Physiological Psychology, 1971, 75, 471-475.

THIESSEN, D. D., OWEN, K., \& LINDZEY, G. Mechanisms of territorial marking in the male and female Mongolian gerbil (Meriones unguiculatus). Journal of Comparative \& Physiological Psychology, 1971, 77, 38-47.

\section{Abnormal Behavior}

BANKER, G., ZORNETZER, S., McGAUGH, J. L., \& COTMAN, C. W. Electroshock effects on brain protein synthesis: Relation to brain seizures and retrograde amnesia. Science, 1971, 173, 454-456.

BOGGAN, W. O., \& SEIDEN, L. S. Dopa reversal of reserpine enhancement of audiogenic seizure susceptibility in mice. Physiology \& Behavior, 1971, 6, 215-217.

BOGGAN, W. O., FREEDMAN, D. X., L O V E L L, R. A ., \& SCHLESINGER, $K$. Studies in audiogenic seizure susceptibility. Psychopharmacologia (Berlin), $1971,20,48-56$.

MCINTYRE, D. C., \& REICHERT, H. State-dependent learning in rats induced by kindled convulsions. Physiology \& Behavior, 1971, 7, 15-20.

SCHREIBER, R. A. Effect of housing density on the incidence of audiogenic seizures in DBA/2J mice. Journal of Comparative \& Physiological Psychology, 1971, 76, 300-304.

S C H R E I B E R, R. A ., \& SCHLESINGER, K. Circadian rhythms and seizure susceptibility: Relation to 5-hydroxytryptamine and norepinephrine in brain. Physiology \& Behavior, 1971, 6, 635-640.

VALZELLI, L., \& BERNASCONI, S. Differential activity of some psychotropic drugs as a function of emotional level in animals. Psychopharmacologia (Berlin), 1971, 20, 91-96.

\section{SENSORY FUNCTIONS Vision \\ Visual Pathways}

ANDERSON, K. V., \& WILLIAMSON, M. R. Visual pattern discrimination in cats after removal of the superior colliculi. Psychonomic Science, 1971, 24, 125-127.

BAKER, B. N., \& WILLIAMS, T. P. Photolysis of metarhodopsin I: Rate and extent of conversion to rhodopsin. Vision Research, 1971, $11,449-458$

BOYNTON, R. M. Visual adaptation in monkey cones: Recordings of late receptor potentials. Science, $1971,170,1423-1425$.

DeVALOIS, R. L. Contours and contrast: Responses of monkey lateral geniculate nucleus cells to luminance and color figures. Science, 1971, 171, 694-696.

DUNSKY, I. L., \& LAPPIN, P. W. Evaluation of retinal thresholds for $C . W$. laser radiation. Vision Research, 1971, 11, 733-738.

FATECHAND, R. The $a_{2}$ component of the vitreal $a$-wave and its intraretinal localization in the frog retina. Vision Research, 1971, 11 , 489-500.

MAINSTER, M. A., WHITE, T. J., \& STEVENS, C. C. Mathematical analysis of rhodopsin kinetics. Vision Research, 1971, 11, $435-447$.

MUNTZ, W. R. A., \& NORTHMORE, D. P. M. Visual pigments from different parts of the retina in rudd and trout. Vision Research, 1971, $11,551-561$.

NAKAYAMA, K. Local adaptation in cat LGN cells: Evidence for a surround antagonism. Vision Research, 1971, 11, 501-509.

NYE, P. W., \& NAKA, K.-I. The dynamics of inhibitory interaction in a frog receptive field: A paradigm of paracontrast. Vision Research, 1971, 11, 377-392.

PEARLMAN, J. T., \& CRESCITELLI, F. Visual pigments of the vitamin A-deficient, thyroidectomized rat following vitamin $\mathrm{A}_{2}$ administration. Vision Research, $1971,11,177-187$.

SHKOLNIK-YARROS, E. G. Neurons of the cat's retina. Vision Research, $1971,11,7-26$.

SPERLING, H. G., \& HARWERTH, R. $S$. Red-green cone interactions in the increment-threshold spectral sensitivity of primates. Science, $1971,172,180-184$.

TATE, C., \& WOOLFSON, M. M. On modelling neural networks in the retina. Vision Research, 1971, 11 , 617-633.

THOMPSON, G. The photopic spectral sensitivity of gulls measured by electroretinographic and pupillometric methods. Vision Research, 1971, 11, 719-731.

TROELSTRA, A. Harmonic distortion in the frog's ERG and its possible relation to differences in latencies. Vision Research, 1971, 11, 393-403.

WULFF, V. J. Modification of the receptor potential of the Limulus lateral eye by current and light. Physiology \& Behavior, 1971, 6, 513-521.

\section{Cortical Functions}

CREEL, D. J. Differences of ipsilateral 
and contralateral visually evoked responses in the cat: Strains compared. Journal of Comparative \& Physiological Psychology, 1971, 77, 161-165.

KILLACKEY, H., \& DIAMOND, I. T. Visual attention in the tree shrew: An ablation study of the striate and extrastriate visual cortex. Science, $1971,171,696.699$.

LEE, J. R., \& POLLEN, D. A. How does the striate cortex begin the reconstruction of the visual world? Science, 1971, 173, 74-77.

MIZE, R. R., WETZEL, Ä: B., \& THOMPSON, V. E. Contour discrimination in the rat following removal of posterior neocortex. Physiology \& Behavior, 1971, 6, 241-246.

SAMUELS, I., BUTTERS, N., \& GOODGLASS, H. Visual memory deficits following cortical and limbic lesions: Effect of field of presentation. Physiology \& Behavior, 1971, 6, 447-452.

STRATTON, L. O. Effects of dark preference on attention to the positive cue in posterior neodecorticated albino rats. Psychonomic Science, 1971, 24, 105-106.

\section{Visual Sensitivity}

ERNST, A. J., ENGBERG, L., \& THOMAS, D. R. On the form of stimulus generalization curves for visual intensity. Journal of the Experimental Analysis of Behavior, $1971,16,177-180$.

HEIN, A., \& DIAMOND, R. M. Independence of the cat's scotopic and photopic systems in acquiring control of visually guided behavior. Journal of Comparative \& Physiological Psychology, 1971, 76, 31-38.

JACOBS, G. H., \& YOLTON, R. L. Visual sensitivity and color vision in ground squirrels. Vision Research, 1971, 11, 511-537.

SKINNER, N. F., \& BEISHON, R. J. Similarities in the color vision of pigeons and man. Journal of Genetic Psychology, 1971, 119, 25-28.

SPERLING, H. G., \& HARWERTH, R. $S$. Red-green cone interactions in the increment-threshold spectral sensitivity of primates. Science, 1971, 172, 180-184.

TAVOLGA, W. N., \& JACOBS, D. W. Scotopic thresholds for monochromatic light in the cichlid fish, Tilapia heudelotii macrocephala. Vision Research, 1971, 11, 713-717.

THORPE, S. A. Behavioral measures of spectral sensitivity of the goldfish at different temperatures. Vision Research, 1971, 11, 419-433.
Visual Perception

BERRYMAN, J. C., FULLERTON, C., $\&$ SLUCKIN, W. Complexity and colour preferences in chicks of different ages. Quarterly Journal of Experimental Psychology, 1971, 23, 255-260.

DYER, R. S. Influences of the visual system upon two-way avoidance learning in the guinea pig. Journal of Comparative \& Physiological Psychology, 1971, 76, 434-440.

GOODWIN, R. H. Behavior of the aquatic turtle (Chrysemys picta) on a modified visual cliff. Journal of Comparative \& Physiological Psychology, 1971, 76, 233-235.

HEIN, A., \& DIAMOND, R. M. Contrasting development of visually triggered and guided movements in kittens with respect to interocular and interlimb equivalence. Journal of Comparative \& Physiological Psychology, 1971, 76, 219-224.

LATTO, R. Visual search in monkeys. Perceptual \& Motor Skills, 1971, 32, 307-312.

PASNAK, R. Brightness contrast in the cat. Perception \& Psychophysics, 1971, 10, 150-152.

ROSSI, P. J. Prism-induced negative aftereffects without food-reinforced feedback in newly hatched chicks. Psychonomic Science, 1971, 24, 141-142.

SCHIFFMAN, H. R. Depth perception of the Syrian hamster as a function of age and photic condition of rearing. Journal of Comparative \& Physiological Psychology, 1971, 76, 491-495.

SOMER VILL, J. W. Motion parallax in the visual cliff situation. Perceptual \& Motor Skills, 1971, 32, 43-53.

WILSON, M. Shifts in categorization and identifiability of visual stimuli by rhesus monkeys. Perception \& Psychophysics, 1971, 10, 271-272.

Z I M M ER M A N N, R. R ., \& HOCHBERG, J. The facilitation of picture discrimination after object discrimination learning in the neonatal monkey and probably vice versa. Psychonomic Science, 1971, $24,239-241$.

\section{Audition}

L O F T US-H I L L S, J . J . , \& LITTLEJOHN, M. J. Mating-call sound intensities of anuran amphibians. Journal of the Acoustical Society of America, $1971,49,1327-1329$.

MILLER, B. V., \& LEVIS, D. J. The effects of long-term auditory exposure upon the behavioral preference of rats for auditory stimuli. Developmental Psychology, $1971,5,178$.

\section{Neurophysiology}

DAIGNEAULT, E. A., \& STOPP, P. E.
A study of the influence of the olivocochlear bundle on the $N_{1}$ responses to repeated tone pulses. Journal of the Acoustical Society of America, 1971, 49, 1896-1897.

KONISHI, T., \& SLEPIAN, J. Z. Effects of the electrical stimulation of the crossed olivocochlear bundle on cochlear potentials recorded with intracochlear electrodes in guinea pigs. Journal of the Acoustical Society of America, 1971, 49, 1762-1769.

LANGFORD, T. L. Olivary responses to dichotic stimuli. Journal of the Acoustical Society of America, 1971, 49, 601-602.

PRICE, G. R. Correspondence between cochlear microphonic sensitivity and behavioral threshold in the cat. Journal of the Acoustical Society of America, 1971, 49, 1899-1901.

WORTHINGTON, D. W., \& DALLOS, P. Spatial patterns of cochlear difference tones. Journal of the Acoustical Society of America, $1971,49,1818-1830$.

\section{Discrimination}

BELL, R. A., NOBLE, M. E., \& DAVES, W. F. Echolocation in the blinded rat. Perception \& Psychophysics, 1971, 10, 112-114. BLUE, S., SHERMAN, J. G., \& PIERREL, R. Differential responding as a function of auditory stimulus intensity without differential reinforcement. Journal of the Experimental Analysis of Behavior, 1971, 15, 371-377.

ELLIOTT, D. N., FRAZIER, L. A., \& HAYDEN, R. C., JR. Relational and absolute cues in auditory discrimination by monkeys. Perception \& Psychophysics, 1971, 10, 278-282.

HARRISON, J. M., DOWNEY, P., SEGAL, M., \& HOWE, M. Control of responding by location of auditory stimuli: Rapid acquisition in monkey and rat. Journal of the Experimental Analysis of Behavior, $1971,15,379-386$.

HEFFNER, R., HEFFNER, H., MASTERTON, B. Behavioral measurements of absolute and frequency-difference thresholds in guinea pig. Journal of the Acoustical Society of America, 1971, 49, 1888-1895.

LUZ, G. A., \& HODGE, D. C. Recovery from impulse-noise induced TTS in monkeys and men: A descriptive model. Journal of the Acoustical Society of America, 1971, 49, 1770-1777.

SIMMONS, J. A. Echolocation in bats: Signal processing of echoes for target range. Science, 1971, 171, 925-927. 
Lower Senses

BRADLEY, R. M., \& MISTRETTA, C. M. Intravascular taste in rats as demonstrated by conditioned aversion to sodium saccharin. Journal of Comparative \& Physiological Psychology, 1971, 75, 186-189.

FAULL, J. R., MEISELMAN, H. L., \& HALPERN, B. P. Tastelessness: A poorly defined concept-The example of quinine ethylcarbonate. Psychological Record, 1971, 21, 219.228.

HARNED, M. A., PARKS, L. H., \& BARTOSHUK, L. M. Taste of water in the cat: Effects on sucrose preference. Science, 1971, 171, 699-701.

ST. OMER, V. V., \& KRAL, P. A. Electroconvulsive shock impedes the learning of taste aversions: Absence of blood-brain-barrier involvement. Psychonomic Science, 1971, 24, 251-252.

SUTKER, L. W. The effect of initial taste preference on subsequent radiation-induced aversive conditioning to saccharin solution. Psychonomic Science, 1971, 25, 1 - 2 .

THOMAN, E. B., \& KORNER, A. F. Effects of vestibular stimulation on the behavior and development of infant rats. Developmental Psychology, 1971, 5, 92-98.

THORNE, B. M., \& O'BRIEN, A. L. The use of olfactory cues in solving a visual discrimination task. Behavior Research Methods \& Instrumentation, 1971, 3, 240.

ZAWALICH, W. S. Gustatory nerve discharge and preference behavior of penicillamine treated rats. Physiology \& Behavior, 1971, 6, 419-423.

\section{PHYSIOLOGICAL PSYCHOLOGY}

\section{BRAIN FUNCTIONS}

BREMILLER, R. A. A rapid technique of preparing frozen sections of small brains. Physiology \& Behavior, $1971,6,463-464$.

BUREŚÝA, O., \& BUREŠ, J. The effect of prolonged cortical spreading depression on consolidation of visual engrams in rats. Psychopharmacologia (Berlin), 1971, 20, 57-65.

GRAFSTEIN, B. Transneuronal transfer of radioactivity in the central nervous system. Science, $1971,172,177-179$.

LANGFORD, A., FREEDMAN, N., \& W H I T A N, D. Further determinants of interhemispheric transfer under spreading depression. Physiology \& Behavior, 1971, 7, 65-71.

ROUTTENBERG, A. Stimulus processing and response execution: A neurobehavioral theory. Physiology \& Behavior, 1971, 6, 589-596.

\section{Lesions}

ANDERSON, K. V., \& WILLIAMSON, M. R. Visual pattern discrimination in cats after removal of thesuperior colliculi. Psychonomic Science, 1971, 24, 125-127.

FLOOD, N. B., \& OVERMIER, J. B. Effects of telencephalic and olfactory lesions on appetitive learning in goldfish. Physiology \& Behavior, 1971, 6, 35-40.

GOODMAN, E. D., JANSEN, P. E., \& DEWSBURY, D. A. Midbrain reticular formation lesions: Habituation to stimulation and copulatory behavior in male rats. Physiology \& Behavior, 1971, 6, 151-156.

HALL, T. L., \& THOMPSON, R. W. Interhemispheric transfer as a function of light intensity discrimination difficulty. Journal of Comparative \& Physiological Psychology, 1971, 77, 166-170.

HAMILTON, C. R. Visual discrimination of movement: Midbrain or forebrain? Science, $1971,170,1428-1430$.

HESTER, G. A. Effects of functional transection of the spinal cord on $t$ ask performance under varied motivational conditions. Psychophysiology, 1971, 8, 451-461.

LORENS, S. A., SORENSEN, J. P., \& YUNGER, L. M. Behavioral and neurochemical effects of lesions in the raphe system of the rat. Journal of Comparative \& Physiological Psychology, 1971, 77, 48-52.

MACPHAIL, E. M. Hyperstriatal lesions in pigeons: Effects on response inhibition, behavioral contrast, and reversal learning. Journal of Comparative \& Physiological Psychology, 1971, 75, 500-507.

MANNING, F. J., GROSS, C. G., \& COWEY, A. Partial reinforcement: Effects on visual learning after foveal prestriate and inferotemporal lesions. Physiology \& Behavior, 1971, 6, 61-64.

MARKS, H. E., REMLEY, N. R., SEAGO, J. D., \& HASTINGS, D. W. Effects of bilateral lesions of the olfactory bulbs of rats on measures of learning and motivation.
Physiology \& Behavior, 1971, 7, 1-6.

MONTGOMERY, R. L., BERKUT, M. K., GRU B B, E. F., \& WESTBROOK, D. L. Hormonal influence on behavior in brain lesioned male rats. Physiology \& Behavior, 1971, 7, 107-111.

PETERS, M., \& MONJAN, A. A. Behavior after cerebellar lesions in cats and monkeys. Physiology \& Behavior, 1971, 6, 205-206.

QUAY, W. B. Effects of cutting nervi conarii and tentofium cerebelli on pineal composition and activity shifting following reversal of photoperiod. :Physiology \& Behavior, 1971, 6,:681-688.

THORNE, B. M., \& LINDER, L. H. No change in emotionality of rats following bulbectomy. Psychonomic Science, 1971, 24, 207-208.

WELLER, C. P., \& SULMAN, F. G. Activity of major analgesics on motor nociceptive responses in d e c e r e brat e mice. Psychopharmacologia (Berlin), 1971, 20, 299-306.

DABROWSKA, J. Dissociation of impairment after lateral and medial prefrontal lesions in dogs. Science, 1971, 171, 1037-1038.

GLICK, S. D., NAKAMURA, R. K., \& JARVIK, M. E. Recovery of function following frontal brain damage in mice: Changes in sensitivity to amphetamine. Journal of Comparative \& Physiological Psychology, 1971, 76, 454-459.

KILLACKEY, H., \& DIAMOND, I. T. Visual attention in the tree shrew: An ablation study of the striate and extrastriate visual cortex. Science, $1971,171,696-699$.

MIZE, R. R., WETZEL, A. B., \& THOMPSON, V. E. Contour discrimination in the rat following removal of posterior neocortex. Physiology \& Behavior, 1971, 6, 241-246.

STEIN, D., BUTTERS, N., \& ROSEN, J. Recovery of function after serial ablation of prefrontal cortex in the rhesus monkey. Science, 1971, 173, 353-356.

STRATTON, L. O. Effects of dark preference on attention to the positive cue in posterior neodecorticated albino rats. Psychonomic Science, 1971, 24, 105-106.

TREICHLER, F. R. Noncorrectional probability learning and reversal by rats: Posterior decortication influence. Physiology \& Behavior, $1971,6,613-615$.

VEGA, A., \& PARSONS, O. A. Lateralized brain damage and differential psychological effects: 